\title{
ANALISIS PERILAKU PENGGUNAAN JAMBAN KELUARGA PADA MAYARAKAT SUKU BAJO DI WILAYAH PESISIR DESA BA-HARI KECAMATAN TOWEA KABUPATEN MUNA TAHUN 2019
}

\author{
Sitti Nur Musdalifah ${ }^{1}$ Yusuf sabilu $^{2}$ Yasnani $^{3}$ \\ 1,2,3 Fakultas Kesehatan Masyarakat Universitas Halu Oleo \\ ${ }^{1}$ sittinurmusdalifah2015@gmail.com²yusufsabilu@yahoo.com³yasnani_rahabuddin @yahoo.com
}

\begin{abstract}
Abstrak
Masalah kondisi lingkungan tempat pembuangan kotoran manusia tidak terlepas dari aspek kepemilikan terhadap sarana yang digunakan. Berdasarkan data dari World Health Organization (WHO) pada tahun 2016 diperkirakan sebesar 1,1 milyar orang atau 17\% penduduk dunia masih Buang Air Besar (BAB) di area terbuka. Tujuan dari penelitian ini adalah untuk mengetahui Perilaku Penggunaan Jamban Keluarga Pada Masyarakat Suku Bajo di Wilayah Pesisir Desa Bahari Kecamatan Towea Kabupaten Muna Tahun 2019. Penelitian ini merupakan jenis penelitian observasional- analitik yang menggunakan rancangan "crosssectional study". Populasi dalam penelitian ini adalah seluruh ru-mah tangga yang berada di Desa Bahari Kecamatan Towea Kabupaten Muna Kelurahan dengan jumlah 446 Ke-pala Keluarga. Sampel berjumlah 82 Kepala Keluarga yang diambil dengan menggunakan tehnik SimpleRand-om Sampling (SRS). Analisis data dilakukan secara univariat dan bivariat menggunakan uji chisquare. Hasil Penelitian menunjukkan Ada hubungan yang bermakna antara pengetahuan dengan penggunaan jamban (nilai $p$-value $=0,034$ ), Tidak ada hubungan yang bermakna antara sikap dengan penggunaan jamban (nilai $p$ val-ue $=0,086$ ), Ada hubungan yang bermakna antara pendapatan dengan penggunaan jamban(nilai $p$ value $=-0,000$ ), Ada hubungan yang bermakna antara peran petugas kesehatan dengan penggunaan jamban (nilai $p$ value $=0,002$ ), Ada hubungan yang bermakna antara kepemilikan jamban dengan penggunaan jamban (nilai $p$ value $=0,033$ ). Kesimpulan pada penelitian ini menunjukan ada hubungan antara variabel Pengetahuan-, Sikap, Pendapatan, Peran Petugas Kesehatan dan Kepemilikan Jamban.
\end{abstract}

Kata kunci : Pengetahuan,Sikap, Pendapatan, Peran Petugas Kesehatan, Kepemilikan Jamban

\begin{abstract}
The problem of the environmental conditio-ns of the disposal of human waste is inseparable from the aspect of ownership of the facilities used. Based o-n data from the World Health Organization (WHO) in 2016 it is estimated that 1.1 billion people or $17 \%$ of the- world's population are still defecating in open areas. The purpose of this study was to determine the behavior -of the use of family latrines in the Bajo community in the coastal region of the Bahari village in Towea sub-district, Muna regency in 2019. This study was an observational analytic study using a "cross sectional study-". The population in this study were all households located in Bahari Village, Towea Sub-District, Muna District, -District with a total of 446 households. A sample of 82 families was taken using the Simple Random Sampli-ng (SRS) technique. Data analysis was done by univariate and bivariate using chi-square test. The results s-howed that there was a significant relationship between knowledge and use of latrines $(p$ value $=0.034)$-. There was a significant relationship between attitudes and use of latrines ( $p$ value $=0.086$ ). There was a significant relationship between use of latrines $(p$ value $=0,000)$, There is a significant relationship between the -role of health workers and the use of latrines ( $p$ value $=0.002$ ), There is a significant relationship between latrine ownership and the use of latrines ( $p$ value = 0.033). The conclusion of this study shows that there is a rela-tionship between the variables of Knowledge, Attitudes, Income, Role of Health Officers and Latrine Ownership.-
\end{abstract}

-Keywords: Knowledge, Attitude, Income, Role of Health Officers, Latrine Ownership 


\section{PENDAHULUAN}

Masalah kondisi lingkungan tempat pembuangan kotoran manusia tidak terlepas dari aspek kepemilikan terhadap sarana yang digunakan. Berdasarkan data dari World Health Organization (WHO) pada tahun 2016 diperkirakan sebesar 1,1 milyar orang atau $17 \%$ penduduk dunia masih Buang Air Besar (BAB) di area terbuka, dari data tersebut sebesar $82 \%$ penduduk yang Buang Air Besar Sembarangan (BABS) terdapat di 10 negara dan Indonesia sebagai negara kedua terbanyak ditemukan masyarakat buang air besar di area terbuka, yaitu India (58\%), Indonesia (12,9\%), China $(4,5 \%)$, Ethiopia $(4,4 \%)$, Pakistan $(4,3 \%)$, Nigeria (3\%), Sudan (1,5\%), Nepal (1,3\%), Brazil $(1,2 \%)$ dan Nigeria $(1,1 \%)$.

Berdasarkan konsep dan definisi Milenium Development Goals (MDGs) yang pada tahun 2016 dilanjutkan dengan Sustainable Development Goals (SDGs), rumah tangga dikatakan memiliki akses sanitasi layak apabila fasiltas sanitasi yang digunakan memenuhi syarat kesehatan antara lain dilengkapi dengan leher angsa, tanki septic (septic tank)/ Sistem Pengolahan Air Limbah (SPAL) yang digunakan sendiri atau bersama. Persentase rumah tangga di Indonesia yang memiliki akses terhadap sanitasi layak tahun 2015 yaitu 60,05\% dan meningkat pada tahun 2016 menjadi $61,08 \%$ serta pada tahun 2017 meningkat menjadi $63,14 \%{ }^{2}$

Masalah kesehatan adalah suatu masalah yang sangat kompleks, yang saling berkaitan dengan masalah-masalah lain di luar kesehatan sendiri. Demikian pula pemecahan masalah kesehatan masyarakat, tidak hanya dilihat dari segi kesehatannya sendiri, tapi harus dilihat dari segisegi yang ada pengaruhnya dengan masalah kesehatan tersebut. Menurut Hendrik L. Bloom ada 4 faktor yang mempengaruhi kesehatan baik kesehatan individu maupun kesehatan masyarakat yaitu keturunan, lingkungan perilaku, dan pelayanan kesehatan. Status kesehatan akan tercapai secara optimal, bilamana keempat faktor tersebut secara bersama-sama mempunyai kondisi yang optimal pula. Jika salah satu faktor saja berada dalam keadaan yang terganggu, maka status kesehatan bergeser dibawah optimal. Sanitasi merupakan hal yang sangat penting untuk menunjang kehidupan masyarakat. Setiap kegiatan masyarakat dalam keseharian memerlukan sanitasi yang baik. Namun tidak semua masyarakat dapat menyediakan dan mengelola sanitasinya dengan baik, hal ini diperkuat berdasarkan data statistik, akses sanitasi dasar di Indonesia sampai dengan tahun 2013 baru mencapai 57,8\%. ${ }^{3}$

Untuk mempertahankan kesehatan yang baik kita harus mencegah banyaknya ancaman yang akan mengganggu kesehatan. Ancaman lainnya terhadap kesehatan adalah pembuangan kotoran (Faces dan Urine) yng tidak pada tempatnya. Buang Air Besar (BAB) di sembarang tempat itu berhaya, karena akan memudahkan terjadinya penyebaran penyakit lewat lalat, udara dan air. Masalah pembuangan kotoran manusia merupakan masalah yang pokok karena kotoran manusia (Faces) adalah sumber penyebaran penyakit multikomples. Beberapa penyakit yang dapat disebarkan oleh tinja manusia antara lain tifus, disentri, kolera, bermacam-macam cacing (gelang, kremi, tambang, pita). ${ }^{4}$

Penggunaan jamban di daerah pedesaan saat ini masih sangat rendah sehingga pencanangan pekan sanitasi yang dilakukan pemerintah diseluruh pedesaan adalah untuk menunjang pembudayaan hidup bersih dan sehat. Hal ini dikemukakan oleh Menteri Kesehatan Republik Indonesia dalam membuka Pentaloka Pekan Sanitasi dan Rekornas Penyehatan Air dan Pengamatan Limbah di Jakarta. Cakupan penggunaan jamban di pedesaan hanya 49,1 \% dan diperkotaan 76,9\%. Pandangan ahli sanitasi yang secara langsung berhubungan dari pembuangan kotoran manusia yang sangat bervariasi, bertitik tolak dari kebersihan masyarakat dalam hubungannya dengan ekonomi serta penyehatan. Sedangkan ahli kesehatan menaruh perhatian besar pada infeksi manusia dan bahwa penyakit berhubungan dengan pembuangan kotoran manusia dan sampah. ${ }^{5}$

Menurut Undang-undang No. 22 tahun 1999 yang terakhir telah disempurnakan melalui Undangundang Nomor 32 Tahun 2004 dinyatakan bahwa wilayah daerah Provinsi terdiri dari wilayah daratan dan wilayah laut sejauh 12 mil laut yang diukur dari garis pantai ke arah laut lepas dan atau kearah perairan kepulauan, sedangkan kewenangan daerah kabupaten/kota sejauh sepertiga dari batas laut daerah Provinsi. Melalui pelimpahan kewenangan tersebut, maka daerah dapat lebih leluasa dalam merencanakan dan mengelola sumberdaya wilayah pesisir, termasuk jasa lingkungan lainnya bagi kepentingan pembangunan daerah itu sendiri. Khususnya wilayah Provinsi Sulawesi Tenggara dengan wilayah lautan lebih luas dari pada daratan yang dikelilingi oleh lautan dan pesisir. ${ }^{6}$ 
Data yang ada menunjukan sebagian besar penduduk Sulawesi Tenggara menggunakan sarana jamban jenis leher angsa dengan presentase mencapai $49 \%$. Secara keseluruhan $69 \%$ penduduk telah memiliki dan menggunakan sarana jamban tetap, meskipun belum semuanya memenuhi syarat. Namun demikian masih terdapat $31 \%$ penduduk yang menggunakan sarana jamban lainnya yang tidak diketahui atau tidak tercatat/tidak dilaporkan, ini akan menjadi masalah bila penduduk tersebut tidak mempunyai jamban tetap dan melakukan aktifitas BAB di tempat terbuka atau sembarang tempat. Persentase penduduk yang memiliki akses terhadap sanitasi layak meningkat menjadi $56,16 \%$ (tahun 2015; $41,36 \%)$. Bisa disimpulkan bahwa rata-rata penduduk Sultra telah menggunakan jamban tetap, tetapi baru kurang lebih setengahnya yang memenuhi syarat jamban sehat atau layak. ${ }^{7}$

Berdasarkan survei awal calon peneliti menemukan keadaan fisik tempat tinggal seluruh masyarakat kawasan Desa Bahari yang berpasir dan sedikit daratan yang dimiliki dengan kondisi rumah tancap yang kabanyakan kurang memadai. Sedangkan dilihat dari profil kesehatan sanitasi lingkungan dasar, daerah tersebut jauh dari yang dikatakan sehat dengan kurang adanya sarana fasilitas lingkungan yang mendukung seperti ketersediaan jamban yang memenuhi syarat sehingga hampir semua masyarakat terbiasa membuang tinja dilaut dengan jamban cemplung atau dihutan mangrove. Fasilitas lain yang masih sangat kurang yaitu ketersediaan air bersih yang sangat dibutuhkan masyarakat desa bahari. Untuk memenuhi kebutuhan tersebut masyarakat membeli air bersih di Desa Moasi yang berbeda daratan dengan Desa Bahari sehingga menyulitkan masyarakat untuk selalu menyediakan air bersih setiap saat.

\section{METODE}

Rancangan penelitian yang digunakan adalah analitik observasional dengan desain cross sectiona/Pada penelitian ini pengambilan variabel dependen dan variabel independen dilakukan dalam waktu yang bersamaan untuk mengetahui faktor-faktor yang berhubungan dengan keberadaan analisis perilaku penggunaan jamban keluarga pada masyarakat suku bajo di wilayah pesisir desa bahari kecamatan towea kabupaten muna tahun 2019. Waktu dan tempat penelitian yakni pada bulan mei 2019 di kecamatan towea kabupaten muna.Populasi dalam penelitian ini adalah semua masyarakat yang ada di desa bahari kecamatan towea kabupaten muna tahun 2019 yang berjumlah 446 kepala keluarga, dan sampel dalam penelitian ini berjumlah 82 responden. Variabel dalam penelitian ini terdiri dari variabel terikat (penggunaan jamban) dan variabel bebas (pengetahuan, sikap, pendapatan, peran petugas, kepemilikan jamban). ${ }^{8}$

HASIL

Tabel 1 Hubungan Pengetahuan Terhadap Perilaku Penggunaan Jamban Keluarga Pada Masyarakat Suku Bajo Di Wilayah Pesisir Desa Bahari Kecamatan Towea Kabupaten Muna Tahun 2019

\begin{tabular}{|c|c|c|c|c|c|c|c|c|}
\hline \multirow{3}{*}{ No } & \multirow{3}{*}{ Pengetahuan } & \multicolumn{4}{|c|}{ Penggunaan Jamban } & \multirow{2}{*}{\multicolumn{2}{|c|}{ Total }} & \multirow{3}{*}{$\begin{array}{c}p \\
\text { Value }\end{array}$} \\
\hline & & \multicolumn{2}{|c|}{$\begin{array}{c}\text { Tidak } \\
\text { Menggunakan }\end{array}$} & \multicolumn{2}{|c|}{ Menggunakan } & & & \\
\hline & & $\mathbf{n}$ & $\%$ & $\mathbf{n}$ & $\%$ & $\mathbf{n}$ & $\%$ & \\
\hline 1. & Sedikit & 39 & 47,6 & 11 & 13,4 & 50 & 61 & \multirow{3}{*}{0,034} \\
\hline 2. & Banyak & 17 & 20,7 & 15 & 18,4 & 32 & 39 & \\
\hline & Total & 56 & 68,3 & 26 & 31,7 & 82 & 100 & \\
\hline
\end{tabular}

Sumber : Data Primer, Tahun 2019

Tabel 2 Hubungan Sikap Terhadap Perilaku Penggunaan Jamban Keluarga Pada Masyarakat Suku Bajo Di Wilayah Pesisir Desa Bahari Kecamatan Towea Kabupaten Muna Tahun 2019

\begin{tabular}{|c|c|c|c|c|c|}
\hline \multirow{3}{*}{ No } & \multirow{3}{*}{ Sikap } & \multicolumn{2}{|c|}{ Penggunaan Jamban } & \multirow[b]{2}{*}{ Total } & \multirow{3}{*}{$\begin{array}{c}p \\
\text { Value }\end{array}$} \\
\hline & & $\begin{array}{c}\text { Tidak } \\
\text { Menggunakan }\end{array}$ & Menggunakan & & \\
\hline & & n $\quad \%$ & $\%$ & $n$ & \\
\hline
\end{tabular}


Jurnal Ilmiah Mahasiswa Kesehatan Masyarakat Vol.5 No.2 April 2020 ; Issn 2502-731X

\begin{tabular}{|c|c|c|c|c|c|c|c|c|}
\hline 1. & Buruk & 18 & 22,0 & 3 & 3,7 & 21 & 25,6 & \multirow{3}{*}{0,086} \\
\hline 2. & Baik & 38 & 46,3 & 23 & 28,0 & 61 & 74,4 & \\
\hline & & 56 & 68,3 & 26 & 31,7 & 82 & 100 & \\
\hline
\end{tabular}

Sumber : Data Primer, Tahun 2019

Tabel 3 Hubungan Pendapatan Terhadap Perilaku Penggunaan Jamban Keluarga Pada Masyarakat Suku Bajo Di Wilayah Pesisir Desa Bahari Kecamatan Towea Kabupaten Muna Tahun 2019

\begin{tabular}{|c|c|c|c|c|c|c|c|c|}
\hline \multirow{3}{*}{ No } & \multirow{3}{*}{ Pendapatan } & \multicolumn{4}{|c|}{ Penggunaan Jamban } & & & \multirow{3}{*}{$\begin{array}{c}p \\
\text { Value }\end{array}$} \\
\hline & & \multicolumn{2}{|c|}{$\begin{array}{c}\text { Tidak } \\
\text { Menggunakan }\end{array}$} & \multicolumn{2}{|c|}{ Menggunakan } & \multicolumn{2}{|c|}{ Total } & \\
\hline & & $n$ & $\%$ & $\mathbf{n}$ & $\%$ & $\mathbf{n}$ & $\%$ & \\
\hline 1. & Rendah & 41 & 50,0 & 6 & 7,3 & 47 & 57,3 & \multirow{3}{*}{0,000} \\
\hline 2. & Tinggi & 15 & 18,3 & 20 & 24,4 & 35 & 42,7 & \\
\hline & Total & 56 & 68,3 & 26 & 31,7 & 82 & 100 & \\
\hline
\end{tabular}

Sumber : Data Primer, Tahun 2019

Hubungan Peran Petugas Terhadap Perilaku Penggunaan Jamban Keluarga Pada

Tabel 4 Masyarakat Suku Bajo Di Wilayah Pesisir Desa Bahari Kecamatan Towea Kabupaten Muna Tahun 2019

\begin{tabular}{|c|c|c|c|c|c|c|c|c|}
\hline \multirow{3}{*}{ No } & \multirow{3}{*}{$\begin{array}{c}\text { Peran Petugas } \\
\text { Kesehatan }\end{array}$} & \multicolumn{4}{|c|}{ Penggunaan Jamban } & \multirow{2}{*}{\multicolumn{2}{|c|}{ Total }} & \multirow{3}{*}{$\begin{array}{c}p \\
\text { Value }\end{array}$} \\
\hline & & \multicolumn{2}{|c|}{$\begin{array}{c}\text { Tidak } \\
\text { Menggunakan }\end{array}$} & \multicolumn{2}{|c|}{ Menggunakan } & & & \\
\hline & & $\mathbf{N}$ & $\%$ & $\mathbf{n}$ & $\%$ & $\mathbf{n}$ & $\%$ & \\
\hline 1. & Kurang & 46 & 56,1 & 12 & 14,6 & 58 & 70,7 & \multirow{3}{*}{0,002} \\
\hline 2. & Sering & 10 & 12,2 & 14 & 17,1 & 24 & 29,3 & \\
\hline \multicolumn{2}{|r|}{ Total } & 56 & 68,3 & 26 & 31,7 & 82 & 100 & \\
\hline
\end{tabular}

Sumber : Data Primer, Tahun 2019

Tabel 5 Hubungan Kepemilikan Jamban Terhadap Perilaku Penggunaan Jamban Keluarga Pada Masyarakat Suku Bajo Di Wilayah Pesisir Desa Bahari Kecamatan Towea Kabupaten Muna Tahun 2019

\begin{tabular}{|c|c|c|c|c|c|c|c|c|}
\hline \multirow{3}{*}{ No } & \multirow{3}{*}{ Kepemilikan Jamban } & \multicolumn{4}{|c|}{ Penggunaan Jamban } & \multirow[b]{3}{*}{$\mathbf{n}$} & & \multirow{3}{*}{$\begin{array}{r}P \\
\text { Value }\end{array}$} \\
\hline & & \multicolumn{2}{|c|}{$\begin{array}{c}\text { Tidak } \\
\text { Menggunakan }\end{array}$} & \multicolumn{2}{|c|}{ Menggunakan } & & \multirow[b]{2}{*}{$\%$} & \\
\hline & & $\mathbf{n}$ & $\%$ & $\mathbf{n}$ & $\%$ & & & \\
\hline 1. & Tidak Memenuhi syarat & 41 & 50,0 & 12 & 14,6 & 53 & 64,6 & \multirow{3}{*}{0,033} \\
\hline 2. & Memenuhi Syarat & 15 & 18,3 & 14 & 17,1 & 29 & 35,4 & \\
\hline & Total & 56 & 68,3 & 26 & 31,7 & 82 & 100 & \\
\hline
\end{tabular}

Sumber : Data Primer, Tahun 2019

DISKUSI

Hubungan Pengetahuan Terhadap Perilaku Penggunaan Jamban Keluarga Pada Masyarakat Suku Bajo Di Wilayah Pesisir Desa Bahari Kecamatan Towea Kabupaten Muna Tahun 2019

Pengetahuan merupakan faktor penting dalam upaya peningkatan pengelolaan jamban keluarga, karena dengan baiknya pengetahuan maka semakin memahami dan mampu melaksanakan upaya pengelolaan jamban keluarga yang baik, baik dalam pemeliharaan, pemeliharaan jamban jika rusak atau tersumbat serta menjaga kebersihan jamban dari berbagai kotoran, sehingga lingkungan tempat tinggal bersih dan sehat serta dapat mencegah terjadinya pencemaran lingkungan. Pengetahuan seseorang didapatkan dari 
pengalaman dan informasi yanmg didapatkan, baik melalui pelatihan, bimbingan, pembinaan maupun melalui pengamatan, sehingga dapat memberikan tanggapan apa yang diamati. ${ }^{9}$

Berdasarkan hasil penelitian yang dilakukan di wilyah pesisir Desa Bahari Kecamatan Towea Kabupaten Muna Tahun 2019 menunjukan bahwa dari 82 responden yang memiliki pengetahuan kurang sebanyak 50 responden $(61,0 \%)$ dan yang memiliki pengetahuan baik sebanyak 32 responden (39,0\%). Responden dengan tingkat pengetahuan kurang yang tidak menggunakan jamban yaitu sebanyak 39 responden $(47,6 \%)$ dan responden dengan tingkat pengetahuan kurang namun menggunakan jamban yaitu sebanyak 11 responden $(13,4 \%)$. Sedangkan responden dengan tingkat pengetahuan baik yang tidak menggunakan jamban yaitu sebanyak 17 responden $(20,7 \%)$ dan responden dengan tingkat pengetahuan baik namun menggunakan jamban yaitu sebanyak 15 responden (18,3\%). ${ }^{10}$

Berdasarkan hasil uji Chi Square menunjukkan nilai $p=0,034$, sehingga dapat disimpulkan bahwa pengetahuan mempunyai hubungan terhadap Perilaku Penggunaan Jamban Keluarga Pada Masyarakat Suku Bajo Di Wilayah Pesisir Desa Bahari Kecamatan Towea Kabupaten Muna Tahun 2019 karena nilai $p<\alpha(0,05)$. Hal ini bermakna bahwa tingkat pengetahuan seseorang sangat mempengaruhi perilaku orang tersebut, dimana semakin baik tingkat pengetahuan seseorang maka semakin tinggi pula tingkat kesadarannya untuk menggunakan jamban dalam keluarga.

Sesuai dengan hasil penelitian yang telah dilakukan maka peneliti dapat menyimpulkan bahwa sebagian besar pengetahuan responden tentang penggunaan jamban sangatlah minim. Hal ini bisa saja disebabkan oleh kurangnya pelaksanaan penyuluhan mengenai penggunaan jamban secara terus menerus dan berkesinambungan. Sesuai dengan teori yang menyatakan bahwa pengetahuan adalah hasil tahu dan terjadi setelah orang melakukan pengindraan terhadap suatu objek tertentu. Sebagian besar pengetahuan manusia diperoleh melalui penglihatan dan pendengaran. Pengetahuan kepala keluarga yang tidak baik mengakibatkan kurangnya kemampuan dalam memanfaatan jamban sehat. Keterbatasan pengetahuan ini akan mengakibatkan dampak yang kurang baik dalam pemeliharaan kesehatan bagi kepala keluarga dan anggota keluarganya.

Menurut asumsi peneliti, masih kurangnya pengetahuan ini sebagai imbas dari rendahnya tingkat pendidikan yang dimiliki oleh responden sehingga pengetahuan responden masih belum memadai mengenai pentingnya jamban dalam menjaga kesehatan pribadi maupun kesehatan lingkungan, responden hanya sekedar tahu tetapi tidak dapat memahami dan menganalisis informasi yang diperoleh. Hal ini terlihat dari pendidikan sebagian besar responden hanya sampai tingkat SD. Ini diperparah lagi dengan minimnya kepemilikan jamban dan dukungan yang diberikan oleh keluarga sehingga masing-masing anggota keluarga belum menyadari dampak dari tindakan tidak memanfaatkan jamban.

Dari aspek masyarakat, yang paling berarti terhadap terjadinya proses perubahan perilaku adalah kepemilikan pengetahuan terhadap pentingnya perilaku baik. Pengetahuan tentang sehat dan kesehatan, dan pengetahuan tentang penyebab sakit dan dampak dari penyakit yang mewabah atau membahayakan, banyak responden tergugah untuk merawat lingkungan dan membangun jamban, justru setelah mengetahui informasi tersebut. Mereka sadar bahwa buang kotoran sembarangan bukan hanya sekedar malu dan dosa, tetapi justru karena tahu dampak negatif dan keburukan lainnya.

Hal ini menunjukkan bahwa responden yang memiliki pengetahuan yang baik tentang pemanfaatan jamban dapat selalu memanfaatkan jamban dengan baik. Sedangkan responden yang memiliki pengetahuan kurang belum dapat mengetahui secara jelas dan efektif tentang pemanfaatan jamban. Pengetahuan yang baik dipengaruhi oleh intensitas perhatian dan persepsi terhadap objek. Menurut Notoatmodjo (2010) bahwa sebagian besar pengetahuan seseorang diperoleh melalui indera pendengaran (telinga) dan indera penglihatan (mata). Pengetahuan seseorang terhadap objek mempunyai intensitas atau tingkat yang berbeda-beda.

Hasil penelitian ini sejalan dengan penelitian yang mengemukakan bahwa apabila penerimaan perilaku baru atau adopsi perilaku didasari oleh pengetahuan, kesadaran dan sikap positif, maka perilaku tersebut akan bersifat langgeng (long lasting). Sebaliknya apabila perilaku tidak didasari oleh pengetahuan dan kesadaran maka tidak akan berlangsung lama. ${ }^{11}$

Penelitian ini sejalan dengan hasil penelitian tentang Faktor-faktor yang berhubungan dengan pemanfaatan jamban keluarga dalam Program Pamsimas di Wilayah Kerja Puskesmas Baruah Gunuang Tahun 2015, yang menunjukkan hasil bahwa terdapat hubungan antara pengetahuan 
dengan pemanfaatan jamban sehat dengan pvalue $=0,008$.

Penelitian ini juga sejalan dengan penelitian Misra (2011) di Kecamatan IX Koto Kabupaten Dharmasraya menyatakan ada hubungan yang bermakna antara pengetahuan dengan pemanfaatan jamban oleh masyarakat di Jorong Silago. Serta hasil penelitian Jumawal tahun 2011 di puskesmas kampung teleng terdapat hubungan yang bermakna antara tingkat pengetahuan kepala keluarga dengan jamban jamban yang sehat sebanyak $44,4 \% .^{12}$

Hubungan Sikap Terhadap Perilaku Penggunaan Jamban Keluarga Pada Masyarakat Suku Bajo Di Wilayah Pesisir Desa Bahari Kecamatan Towea Kabupaten Muna Tahun 2019

Sikap merupakan reaksi atau respon sesorang yang masih tertutup terhadap suatu stimulus atau objek. Manifestasi sikap tidak dapat langsung dilihat, tetapi hanya dapat ditafsirkan terlebih dahulu dari perilaku yang tertutup. Sikap secara nyata menunjukkan konotasi adanya kesesuaian reaksi terhadap stimulus tertentu yang dalam kehidupan sehari-hari merupakan reaksi yang bersifat emosional terhadap stimulus sosial. Sikap belum merupakan suatu tindakan atau aktivitas, akan tetapi merupakan "pre-disposisi" tindakan atau perilaku. Sikap itu masih merupakan reaksi tertutup, bukan merupakan reaksi terbuka tingkah laku yang terbuka. ${ }^{13}$

Berdasarkan hasil uji Chi Square menunjukkan nilai $p=0,086$, sehingga dapat disimpulkan bahwa sikap tidak mempunyai hubungan terhadap Perilaku Penggunaan Jamban Keluarga Pada Masyarakat Suku Bajo Di Wilayah Pesisir Desa Bahari Kecamatan Towea Kabupaten Muna Tahun 2019 karena nilai $p<\alpha(0,05)$. Hal ini bermakna bahwa sikap seseorang tidak selalu mempengaruhi perilaku orang tersebut untuk menggunakan jamban keluarga dengan baik. Meskipun sikap orang tersebut baik, belum tentu menjamin perilakunya untuk menggunakan jamban keluarga karena mungkin ada faktor kebiasaan dan rasa nyaman sehingga membuang tinja disembarang tempat.

Berdasarkan hasil penelitian yang dilakukan di wilyah pesisir Desa Bahari Kecamatan Towea Kabupaten Muna Tahun 2019 menunjukan bahwa dari 82 responden yang memiliki sikap buruk terhadap penggunaan jamban sebanyak 21 responden $(25,6 \%)$ dan yang memiliki sikap baik terhadap penggunaan jamban sebanyak 61 responden (74,4\%). Responden dengan sikap buruk yang tidak menggunakan jamban yaitu sebanyak 18 responden $(22,0 \%)$ dan responden dengan sikap buruk namun menggunakan jamban yaitu sebanyak 3 responden (3,7\%). Sedangkan responden dengan sikap baik yang tidak menggunakan jamban yaitu sebanyak 38 responden $(46,3 \%)$ dan responden dengan sikap baik serta menggunakan jamban yaitu sebanyak 23 responden (28,0\%).

Sikap adalah juga respon tertutup pada seseorang terhadap stimulus atau objek tertentu yang sudah melibatkan pendapat dan emosi yang bersangkutan (suka-tidak suka, setuju-tidak setuju). Sikap adalah kumpulan gejala yang merespon stimulus atau objek, sehingga sikap itu melibatkan pikiran, perasaan, perhatian dan sebagainya. penelitian ini menunjukkan bahwa sikap mempunyai malabsorbsi, alergi, keracunan, imunodefisiensi dan penyebab lain. Hal ini lebih ditegaskan lagi oleh sikap itu merupakan kesiapan atau kesediaan untuk bertindak. Sikap merupakan predisposisi tindakan suatu objek, dan sikap itu masih merupakan reaksi tertutup dan memiliki 3 komponen pokok yaitu kepercayaan, emosional dan kecenderungan untuk bertindak. Dalam penentuan sikap yang utuh emosional memegang peranan penting.

Berdasarkan hasil penelitian sikap merupakan salah satu faktor penting yang dapat mempengaruhi seseorang untuk melakukan sesuatu seperti halnya melakukan pembangunan suatu jamban keluarga yang memenuhi syarat di rumah sehingga dalam penggunaan jamban dapat memenuhi syarat kesehatan seperti penggunaan jamban leher angsa.

\footnotetext{
Hubungan Pendapatan Terhadap Perilaku Penggunaan Jamban Keluarga Pada Masyarakat Suku Bajo Di Wilayah Pesisir Desa Bahari Kecamatan Towea Kabupaten Muna Tahun 2019

Pendapatan Keluarga adalah pendapatan yang diperoleh dengan jalan menjual factor-faktor produksi yang akan diperoleh imbalan jasa-jasa atas pengadaan factor produksi tersebut dalam bentuk gaji, sewa tanah, modal kerja dan sebagainya. Besarnya pendapatan akan menggambarkan ekonomi keluarga dalam masyarakat yang dapat dikategorikan dalam tiga kelompok yaitu pendapatan rendah, sedang, dan tinggi. Suatu keluarga pada umumnya terdiri dari suami, isteri, dan anak-anak, besarnya jumlah anggota keluarga akan lebih banyak tersedia tenaga kerja untuk mencari pekerjaan agar memperoleh pendapatan. Umumnya kepala keluarga menentu utama pendapatan keluarga, namun sebenarnya dalam anggota keluarga lainnya juga ikut berperan. ${ }^{14}$
} 
Berdasarkan hasil uji Chi Square menunjukkan nilai $p=0,000$, sehingga -dapat disimpulkan bahwa pendapatan mempunyai hubungan terhadap Perilaku -Penggunaan Jamban Keluarga Pada Masyarakat Suku Bajo Di Wilayah Pesisir --Desa Bahari Kecamatan Towea Kabupaten -Muna Tahun 2019 karena nilai $p<\alpha(-0,05)$. Hal ini bermakna bahwa semakin -tinggi pendapatan seseorang maka semakin -tinggi juga kesadarannya untuk menyediakan dan menggunakan jamban k-eluarga, begitupun sebaliknya.

Berdasarkan hasil penelitian yang dilakuka-n di wilyah pesisir Desa Bahari Kecamat-an Towea Kabupaten Muna Tahun 20-19 menunjukan bahwa dari 82 responden- yang memiliki pendapatan rendah seb-anyak 47 responden $(57,3 \%)$ dan yang memiliki pendapatan tinggi sebanyak 35 responden $(42,7 \%)$. Responden dengan tingkat pendapatan rendah yang tidak menggunakan jamban yaitu sebanyak 41 responden (50,0\%) dan responden dengan tingkat pendapatan rendah namun menggunakan jamban yaitu sebanyak 6 responden (7,3\%). Sedangkan responden dengan tingkat pendapatan tinggi yang tidak menggunakan jamban yaitu sebanyak 15 responden (18,3\%) dan responden dengan tingkat pendapatan tinggi namun menggunakan jamban yaitu sebanyak 20 responden $(24,4 \%)$.

Hasil penelitian ini sejalan dengan penelitian bahwa pendapatan berhubungan dengan perilaku Buang Air Besar Sembarangan (BABS). Dalam penelitiannya menunjukkan bahwa faktor yang berhubungan terhadap perilaku buang air besar sembarangan adalah status ekonomi. Pada variabel pendapatan ditunjukkan dengan masyarakat yang pada umumnya berada pada tingkat ekonomi tinggi sehingga masyarakat mudah atau mampu untuk membangun fasilitas jamban sehingga berpengaruh pada penggunaan maupun pemanfaatan Jamban.

Hasil yang sama didapatkan dari penelitian tentang hubungan karakteristik kepala keluarga dengan tingkat kepemilikan jamban di Kelurahan Bener di Kecamatan Tegal Rejo Kota Yogyakarta dimana didapati bahwa ada hubungan yang bermakna antara pendapatan dengan kepemilikan jamban keluarga. ${ }^{15}$

\footnotetext{
Hubungan Peran Petugas Terhadap Perilaku Penggunaan Jamban Keluarga Pada Masyarakat Suku Bajo Di Wilayah Pesisir Desa Bahari Kecamatan Towea Kabupaten Muna Tahun 2019

Peran petugas adalah upaya pemberdayaan masyarakat yang dilakukan oleh petugas untuk menumbuhkan dan meningkatkan pengetahuan,
}

kemauan dan kemampuan individu, keluarganya dan masyarakat untuk mencegah penyakit, meningkatkan kesehatannya, menciptakan lingkungan serta aktif dalam penyelenggaraan setiap upaya kesehatan. Pemberdaya-an terhadap individu, keluarga dan masyarakat yang diselenggarakan harus memperhatik-an kondisi dan situasi khusu-snya social bu-daya setempat. ${ }^{16}$

Berdas-arkan hasil penelitian yang dilakukan di -wilyah pesisir Desa Bahari Kecamatan To-wea Kabupaten Muna Tahun 2019 menunjuk-an bahwa dari 82 responden yang mendapatk-an penyuluhan kurang dari petugas kesehatan sebanyak 58 responden $(70,7 \%)$ dan yang- mendapatkan penyuluhan sering dari p-etugas kesehatan sebanyak 24 responden (29-,7\%). Responden yang mendapatkan penyu-luhan kurang dari petugas kesehatan yang -tidak menggunakan jamban yaitu sebanya-k 46 responden $(56,1 \%)$ dan responden yang mendapatkan penyuluhan kurang -dari petugas kesehatan namu-n menggunakan jamban yaitu sebanyak 12 respon-den (14,6\%). Sedangkan responden y-ang mendapatkan penyuluhan sering dari petugas kesehatan yang tidak men-gguna-kan jamban yaitu sebanyak 10 responden $-(12,2 \%)$ dan responden yang mendapatkan -penyuluhan sering dari petugas kesehatan -namun menggunakan jamban yaitu -sebanyak 14 responden (17,1\%).

Hasil uji Chi Square menunjukkan -nilai $p=0$, 002, sehingga dapat disimpulkan -bahwa peran petugas kesehatan mempunyai h-ubungan terhadap Perilaku Penggunaan Ja-mban Keluarga Pada Masyarakat Suku Ba-jo Di Wilayah Pesisir Desa Bahari Kec-amatan Towea Kabupaten Muna Tahun 2019 karena nilai $p<\alpha(0,05)$. Hal ini bermakna bahwa semakin sering petugas -kesehatan memberikan penyuluhan dan -pemahaman tentang penggunaan jamban -yang sehat pada keluarga maka semakin -tinggi juga kesadaran keluarga tersebut -untuk menggunakan jamban, begitu pula sebaliknya.

Penelitian ini juga sejalan dengan penelitia-n Safitri tahun 2008 tentang faktor yang berhubungan dengan pembangunan jamban -keluarga yang sehat mengatakan petugas y-ang memberikan dukungan kurang baik $-(77,3 \%)$ lebih tinggi dari pada petugas yang- memberikan dukungan yang baik $(53,4 \%)$, dari hasil uji statistik dapat disimpulkan tidak ada hubungan antara partisipasi responden dengan dukungan petugas. ${ }^{17}$

Hubungan Kepemilikan Jamban Terhadap Perilaku Penggunaan Jamban Keluarga Pada Masyarakat 
Suku Bajo Di Wilayah Pesisir Desa Bahari Kecamatan Towea Kabupaten Muna Tahun 2019

Kepemilikan jamban keluarga juga mengandung unsur mendidik, maksudnya adalah dengan adanya jamban keluarga maka setiap anggota keluarga yang memiliki jamban tidak akan membiasakan diri membuang kotorannya disembarang tempat. Oleh karena itu, agar jamban dapat berfungsi dengan baik, maka harus dibuat jamban yang memenuhi syarat. ${ }^{18}$

Fasilitas merupakan suatu faktor pendukung pengelolaan jamban keluarga yang baik. Oleh karena itu perlu tersedianya fasilitas yang mencukupi, karena tanpa adanya fasilitas maka usaha pengelolaan jamban keluarga tidak dapat dilakukan. Akan tetapi, kurangnya pendapatan keluarga menajdi faktor tidak tersedianya fasilitas pendukung dalam penggunaan jamban yang memenuhi syarat kesehatan, faktor pengetahuan juga merupakan faktor pendukung dalam tersedianya fasilitas agar penggunaan jamban menjadi lebih baik. Dengan penggunaan jamban yang memenuhi syarat maka masyarakat dapat terhindar dari penyakit yang dapat ditimbulkan akibat jamban yang tidak sehat, karena banyaknya faktor pembawa penyakit yang barada pada jamban yang tidak memenuhi syarat. ${ }^{19}$

Hasil uji Chi Square menunjukkan nilai $p=$ 0,033, sehingga dapat disimpulkan bahwa kepemilikan jamban mempunyai hubungan terhadap Perilaku Penggunaan Jamban Keluarga Pada Masyarakat Suku Bajo Di Wilayah Pesisir Desa Bahari Kecamatan Towea Kabupaten Muna Tahun 2019 karena nilai $p<\alpha(0,05)$. Hal ini bermakna bahwa semakin banyak jamban yang dimilki oleh masyarakat baik itu memenuhi syarat kesehatan atau tidak memenuhi syarat kesehatan maka perilaku untuk menggu-nakan jamban tersebut akan semakin baik ju-ga.

Berdasar-kan hasil penelitian yang dilakukan di wilyah pesisir Desa Bahari Kecamatan Tow-ea Kabupaten Muna Tahun 2019 menunjuka-n bahwa dari 82 responden yang memiliki -jamban tidak memenuhi syarat sebanyak 5-3 responden (64,6\%) dan yang memiliki ja-mban memenuhi syarat sebanyak 29 respon-den (35,4\%). Responden yang memilik-i jamban tidak memenuhi syarat dan tida-k menggunakan jamban yaitu sebanyak 41 responden $(50,0 \%)$ dan responden -yang memiliki jamban tidak memenuhi -syarat namun menggunakan jamban yaitu- sebanyak 12 responden (14,6\%). Sedang-kan responden yang memiliki jamban meme-nuhi syarat dan tidak menggunakan ja-mban yaitu sebanyak 15 responden (1-8,3\%) dan responden yang memiliki jamban memenuhi syarat namun menggunakan jamban yaitu sebanyak 14 responden (17,1\%).-

Hasil ini berbeda denga-n penelitian tentang Studi Faktor - Fa-ktor yang mempengaruhi partisipasi- dalam penggunaan jamban di kota Kabanjahe hasil uji Chi Square terlihat pe-rsentase responden kondisi jamban yang m-emenuhi syarat $(45,6 \%)$ berpartisipasi baik dan $54,4 \%$ berpartisipasi tidak baik. hal ini menunjukkan secara persentase tidak ada perbedaan antara jamban yang memenuhi syarat dan tidak memenuhi syarat tidak ada hubungan bermakna antara kondisi jamban terhadap partisipasi keluarga. ${ }^{20}$

Hasil penelitian ini sejalan dengan penelitian yang menunjukkan bahwa masi ada sebagian masyarakat di wilayah kerja Puskesmas Benu-Benua yang balitanya saat membuang air besar tidak di dalam jamban atau menggunakan jamban yang tidak memenuhi syarat kesehatan. Bukannya hal remeh sebenarnya membuang tinja balita, lebih baik di buangdi jamban, karena tinja dapat sebagai sumber penularan penyakit yang potensial terutama bakteri dan virus pathogen (penyebab diare) yang berada didalam usus manusia akan menginfeksi manusia melalui sumber air bersih (sumur gali, sumur pompa tangan, sumber air PDAM dan sungai), tanah, serangga maupun makanan dan minuman yang tercemar. Kemungkinan ini sangat besarterja disebabkan masih banyaknya penduduk di wilayah kerja Puskesmas dengan total tanah yang sempit sehingga memudahkan terjadinya pencemaran sumber air dengan jamban yang kurang dari 10 meter jaraknya. ${ }^{21}$

Hasil penelitian ini sejalan dengan penelitian tentang pembuangan tinja yang sembarangan akan menimbulkan penyebaran penyakit yang multi kompleks. Penyebaran penyakit yang bersumber dari feses dapat melalui berbagai macam jalan dan cara baik melalui air, tangan, lalat maupun tanah yang terkontaminasi oleh tinja dan ditularkan lewat makanan dan minuman secara langsung atau melalui vektor serangga (lalat, kecoa). ${ }^{22}$

\section{SIMPULAN}

1. Ada hubungan yang bermakna antara pengetahuan dengan penggunaan jamban di wilayah pesisir Desa Bahari Kecamatan Towea Kabupaten Muna Tahun 2019, dengan hasil uji chi square menunjukkan nilai $p=0,034$. Maksudnya bahwa tingkat pengetahuan seseorang sangat mempengaruhi perilaku orang tersebut, dimana semakin baik tingkat pengetahuan seseorang maka semakin tinggi 
pula tingkat kesadarannya untuk menggunakan jamban dalam keluarga.

2. Tidak ada hubungan yang bermakna antara sikap dengan penggunaan jamban di wilayah pesisir Desa Bahari Kecamatan Towea Kabupaten Muna Tahun 2019, dengan hasil uji chi square menunjukkan nilai $p=0,086$. Maksudnya bahwa sikap seseorang tidak selalu mempengaruhi perilaku orang tersebut untuk menggunakan jamban keluarga dengan baik. Meskipun sikap orang tersebut baik, belum tentu menjamin perilakunya untuk menggunakan jamban keluarga karena mungkin ada faktor kebiasaan dan rasa nyaman sehingga membuang tinja disembarang tempat.

3. Ada hubungan yang bermakna antara pendapatan dengan penggunaan jamban di wilayah pesisir Desa Bahari Kecamatan Towea Kabupaten Muna Tahun 2019, dengan hasil uji chi square menunjukkan nilai $p=0,000$. Maksudnya bahwa semakin tinggi pendapatan seseorang maka semakin tinggi juga kesadarannya untuk menyediakan dan menggunakan jamban keluarga, begitupun sebaliknya.

4. Ada hubungan yang bermakna antara peran petugas kesehatan dengan penggunaan jamban di wilayah pesisir Desa Bahari Kecamatan Towea Kabupaten Muna Tahun 2019, dengan hasil uji chi square menunjukkan nilai $p=0,002$. Maksudnya bahwa semakin sering petugas kesehatan memberikan penyuluhan dan pemahaman tentang penggunaan jamban yang sehat pada keluarga maka semakin tinggi juga kesadaran keluarga tersebut untuk menggunakan jamban, begitu pula sebaliknya.

5. Ada hubungan yang bermakna antara kepemilikan jamban dengan penggunaan jamban di wilayah pesisir Desa Bahari Kecamatan Towea Kabupaten Muna Tahun 2019, dengan hasil uji chi square menunjukkan nilai $p=0,033$. Maksudnya bahwa semakin banyak jamban yang dimilki oleh masyarakat baik itu memenuhi syarat kesehatan atau tidak memenuhi syarat kesehatan maka perilaku untuk menggunakan jamban tersebut akan semakin baik juga.

\section{SARAN}

Berdasarkan hasil Analisis Perilaku Penggunaan Jamban Keluarga Pada Masyarakat Suku Bajo di wilayah pesisir Desa Bahari Kecamatan Towea Kabupaten Muna Tahun 2019. Maka dapat dikemukakan saran sebagai berikut :

\section{Bagi Masyarakat Desa Bahari Kecamatan Towea}

Perlunya memperhatikan masalah penggunaan jamban yang baik dalam hal ini memenuhi syarat kesehatan agar supaya bisa terhindar dari berbagai masalah penyakit yang mungkin bisa timbul akibat dari kebiasaan buang air besar di sembarang tempat.

2. Bagi Petugas Kesehatan

Perlu dilakukan kembali evaluasi mengenai program penyuluhan di masyarakat pesisir Desa Bahari agar proses penyuluhan mengenai jamban sehat di masyarakat di upayakan bisa efisien dan melakukan bimbingan teknis kepada masyarakat mengenai cara pembuatan jamban sehat di wilayah pesisir.

3. Bagi Peneliti Selanjutnya

Perlu adanya tindak lanjut mengenai penelitian ini yang berkaitan dengan perilaku masyarakat suku bajo terhadap pengelolaan jamban sehat dengan menggunakan metode penelitian kualitatif agar informasi yang didapatkan lebih jelas.

\section{DAFTAR PUSTAKA}

1. WHO. 2017. Progres Sanitasi Dan Air Minum Progress on Sanitation and Drinking-Water. Update. Geneva:WHO 2017.

2. Kemenkes RI. 2018. Peraturan Menteri Kesehatan RI nomor 416 tahun 1990 tentang Syarat-Syarat dan Pengawasan Kualitas Air. Jakarta: Kementerian Kesehatan RI.

3. Mayya. 2011. Hubungan Perilaku Masyarakat Nelayan Dengan Penggunaan Jamban Sehat di Dusun Bagan Desa Percut Kecamatan Percut Sei Tuan Kabupaten Deli Serdang Tahun 2011.

4. Notoatmodjo, S. 2007. Promosi Kesehatan Teori dan Aplikasi. Jakarta: Rineka Cipta.

5. Depkes RI. 2009. Profil Kesehatan Indonesia Departemen Kesehatan Repuplik Indonesia, Jakarta.

6. Muttaqiena. 2015. Pengelolahan Wilayah Pesisir Secara Berkelanjutan Pasca Sunami Desember 2004. Jimkesmas, 2(5), 3-7..

7. Dinkes Sultra. Profil Kesehatan Sulawesi Tenggara (2017).

8. Hayden, J. 2009. Introduction to Health Behaviour Theory. University of Arcansas.

9. Machfoedz, I. 2009. Menjaga Kesehatan Rumah Dari Berbagai Penyakit. Yogyakarta: Fitramaya.

10. Murwati. 2012. Faktor Host Dan Lingkungan Yang Mempengaruhi Perilaku Buang Air Besar Sembarangan/ (Open Defecation). Tesis. Universitas Diponegoro Semarang.

11. Mukherje, N. 2011. Factor Associataed with 
Achieving And Substaning Open Defecation Free Communities: Learning From East Java. Water and Sanitation Program.

12. Notoatmodjo, S. 2003. Pendidikan dan Perilaku Kesehatan. Jakarta: Rineka Cipta.

13. Notoatmodjo, S. 2005. Metodologi Penelitian Kesehatan. Jakarta: Rineka Cipta.

14. Darmawan. (2012). Prinsip-Prinsip Perilaku Organisasi. Surabaya: Pena Semesta.

15. Febriwanti, I,. 2010, hubungan karakteristik kepala keluarga dengan tingkat kepemilikan jamban di kelurahan Bener KecamatanTegal Rejo Kota Yogyakarta, Skripsi, Universitas Ahmad Dahlan.

16. Kemenkes RI. 2014. Peraturan Menteri Kesehatan RI Nomor 3 tentang Sanitasi Total Berbasis Masyarakat. Jakarta: Kementrian Kesehatan RI.

17. Sara, at.al 2014. Ending Open Defecation in Rural Tanzania: Which Factors Facilitate Latrine Adoption?. International Journal Research.ISSN 1660-4601.

18. Proverawati, dkk. 2012. Perilaku Hidup Bersih Dan Sehat. Yokyakarta: Nuha Medika.

19. Tarigan, E. 2014, Faktor Faktor Yang Mempengaruhi Partisipasi Keluarga Dalam Penggunaan Jamban Di Kota Kabanjahe Tahun 2014. Tesis, Universitas Sumatera Utara.

20. Sara, at.al 2014. Ending Open Defecation in Rural Tanzania: Which Factors Facilitate Latrine Adoption?. International Journal Research.ISSN 1660-4601.

21. Dewi Grafikak, Yusuf Sabilu, Sabril Munandar. 2017. Faktor Risiko Kurangnya Perilaku Hidup Bersih Dan Sehat (Phbs) Tatanan Rumah Tangga Terhadap Kejadian Diare Pada Balita Di Wilayah Kerja Puskesmas Benu-Benua Kota Kendari.JIMKESMAS 2(7),Agustus 2017:1-10.

22. Sarnita Nurnaningsi, Yusuf Sabilu M.Si, Andi Faisal Fachlevy, 2017. Faktor Yang Berhubungan Dengan Kejadian Diare Pada Balita Di Wilayah Kerja Puskesmas Abeli Bagian Pesisir Kota Kendari.JIMKESMAS ,2(6) Mei,2017:1-11. 